Article

\title{
Sustainable Streetscapes: Design Approaches and Examples of Viennese Practice
}

\author{
Jürgen Furchtlehner *, Daniela Lehner and Lilli Lička
}

Citation: Furchtlehner, J.; Lehner, D.; Lička, L. Sustainable Streetscapes:

Design Approaches and Examples of Viennese Practice. Sustainability 2022, 14, 961. https://doi.org/10.3390/ su14020961

Academic Editor: Miguel Amado

Received: 28 October 2021

Accepted: 10 January 2022

Published: 15 January 2022

Publisher's Note: MDPI stays neutral with regard to jurisdictional claims in published maps and institutional affiliations.

Copyright: (C) 2022 by the authors. Licensee MDPI, Basel, Switzerland. This article is an open access article distributed under the terms and conditions of the Creative Commons Attribution (CC BY) license (https:// creativecommons.org/licenses/by/ $4.0 /)$.
Institute of Landscape Architecture, University of Natural Resources and Life Sciences, Peter-Jordan-Strasse 65, 1180 Vienna, Austria; daniela.lehner@boku.ac.at (D.L.); lilli.licka@boku.ac.at (L.L.)

* Correspondence: juergen.furchtlehner@boku.ac.at; Tel.: +43-1-4765485231

\begin{abstract}
Streets are ubiquitous and cater to various functions in a city. However, today most streets are unilaterally used and designed likewise. Car-centred spatial distribution is currently being questioned in the course of urban densification and in light of climate and ecological challenges. The presented work focuses on a multi-layered transformation of streetscapes towards a multi-purpose social and ecological space, which goes beyond a mere redistribution of space and functions. This paper draws from the results of an interdisciplinary research project headed by the Institute of Landscape Architecture (University of Natural Resources and Life Sciences, Vienna). The Viennese situation is aligned with international trends. The research includes comparative analysis of streetscapes in Vienna and comparable cities, literature reviews, collaborative workshops and qualitative interviews. As a result, progressive layout specifications and quality aspects for future streets are proposed and presented in extracts. Furthermore, the goal of green space social equity is linked. The paper concludes by arguing for comprehensive consideration and redesign of streetscapes as one promising puzzle to counteract the evident challenges of climate change in urban settings. Its range reaches from small scale microclimatic improvements up to citywide provision of accessible, useable, ecologically sound and sustainable public space with new standards for streets as potential backbone.
\end{abstract}

Keywords: streets as green infrastructure; street transformation; sustainable streets; street design; spatial distribution; public space

\section{Introduction}

Today, cities are struggling with a shortage of space and the need for climate adaption in the course of increasing urban densification. The benefits and values of green infrastructure (GI) are widely studied and recognised [1-5]. Wang and Banzhaf [6] summarise these benefits and identify multifunctionality as "state of the art" of the evolving GI concept. Particularly in the context of climate change enhancing, GI is a promoted and validated approach to mitigate the impacts of increased temperatures and extreme weather events in urban areas [7,8]. Additionally, in the context of social and health benefits, GI is a major player in making or keeping cities liveable by forming a network of recreational spaces of different sizes and forms. Benedict and McMahon call it "an interconnected network of greenspaces that conserves natural ecosystem values and functions and provides associated benefits to human populations" [9] (p. 5) that is "essential to producing the ecosystem services critical to sustaining life and supporting human health" [9] (p. 13).

In addition to scientific studies, a growing number of residents are demanding more green space, more useable public space and a higher quality of amenities, as underlined by exemplary surveys from Vienna or Copenhagen $[10,11]$. However, this desire is opposed to rapid population growth. Densification is being implemented as a common approach in urban planning, resulting in increasing pressure on the remaining open spaces. One of the most pressing problems is the provision of enough publicly useable green space on a neighbourhood scale. At the same time, streets hold up to $90 \%$ of public space in densely 
built urban areas, as shown by calculations from Vienna [12,13]. They are ubiquitous and thus hold considerable spatial potential to fulfil various functions. Yet, as a result of the carcentered urban planning of the last few decades, today most streets are unilaterally used and designed likewise. Two-thirds of an average urban street is dedicated to car traffic, whether that be driving lanes or parking lots with little or no value as green infrastructure. This number is true for Vienna but applies similarly to other European cities [12]. Consequently, streets present a potential for green, lively and just cities by compensating for the lack of green spaces in the neighbourhoods [14,15]. Streets-especially those developed as green streets — can be "considered as a sustainable development approach, fulfilling a variety of environmental, social, and economic objectives" [15] (p. 18). A study [15] compiles various definitions of green streets in the US, whereas green streets are most commonly described as "an effective and affordable tool that treats stormwater with plants and soils pursuing multiple benefits for the better quality of life" [15] (p. 18). While the concept may be only partially or incompletely understood in the US, other countries understand green streets as a multi-vision approach that goes beyond stormwater management $[15,16]$. GI in streets provides many other benefits, "making green street programs an attractive option in working towards sustainability" [16] (p. 14). Cities and their administrations, as well as scholars, are currently drawing attention to this spatial resource and are rethinking the streets' design and function in order to address spatial scarcity and the call for more greenery [4,17-20]. As large linear open spaces, the cities' streets are almost completely under municipal responsibility and may form part of a connecting green grid. It is widely argued that such a greenery-based model can underpin improvements in environmental conditions and an increased quality of life $[5,9,17,21,22]$. Areas shaded by trees were identified as the coolest spots in street canyons [23] and street greenery forms a convenient adaptive strategy to create thermally comfortable living environments [24]. Street-level GI interventions also have a positive impact on the individuals' perceptions of the subjective wellbeing [1,25]. Although there are many benefits to turning streets into green, everyday public spaces beyond mobility and traffic, in many places it is proving difficult to gain or redistribute the necessary space in the traditional streetscape and to undertake transformations.

Whereas minimum standards and requirements for green spaces (such as parks or green corridors) exist in many cities as they do in Vienna [26-30], such supporting numbers are missing for hard surface public space, which in Vienna is composed of squares and streets. Further, Vienna's land-use plan lacks specific definitions for these parts. As a result, all hard surfaces are primarily perceived, designed and used as traffic space for cars and not as places for people, social exchange or ecological functions. However, there are strictly specified widths for driving lanes or car parking; the leftover space is available for other uses. The demand for a minimum width of $2 \mathrm{~m}$ of sidewalks is not even reached in $40 \%$ of all Viennese streets [31], hindering perception and use of streets as multifunctional spaces beyond transit. The planting of trees along streets is also not regulated and-as an earlier survey revealed - on average, only 3 out of 10 Viennese neighbourhood streets offer greening [12]. This is where the presented study hooks and elaborates on recommendations and new standards for future streets in Vienna.

Based on these considerations, the paper elaborates on the questions of how streets can be designed as more sustainable in order to fulfill a wider range of functions, including GI in urban settings, and how to distribute the available space. Due to the lack of minimum standards within this respect for Vienna's streets and the car-centered design of streets, their potential as part of a green network cannot be exploited. In order to meet the requirements of a multifunctional street space (as part of a green and liveable city) the first step must be a spatial redistribution and greener redesign of the traditional street. Therefore, the study aims to highlight the need for restructuring by inventorying the current distribution of public space in exemplary Viennese quarters. Furthermore, the study strives to present new recommendations for streets in order to ensure, at an early planning stage, the creation of a public space whose function goes beyond traffic. 
First, we will discuss the contemporary role of streets with regard to current and future needs. We highlight the functional, ecological, social, and economic aspects which strongly suggest transformation and spatial redistribution processes. At the level of planning policies, we explore quantitative and qualitative requirements to facilitate the transformation from a car-centered street design to a sustainable streetscape in favour of climate adaption and urban living conditions. A literature review, national and international planning documents, expert interviews and case studies serve as basis. As a second step, recommendations for qualitatively and quantitatively futureproof urban streets in Vienna are presented, including layout specifications. We will not present a one-fits-all solution but deliver a minimum standard that allows for flexible adaptation for all street typologies and furthers GI and sustainability (Figure 1).

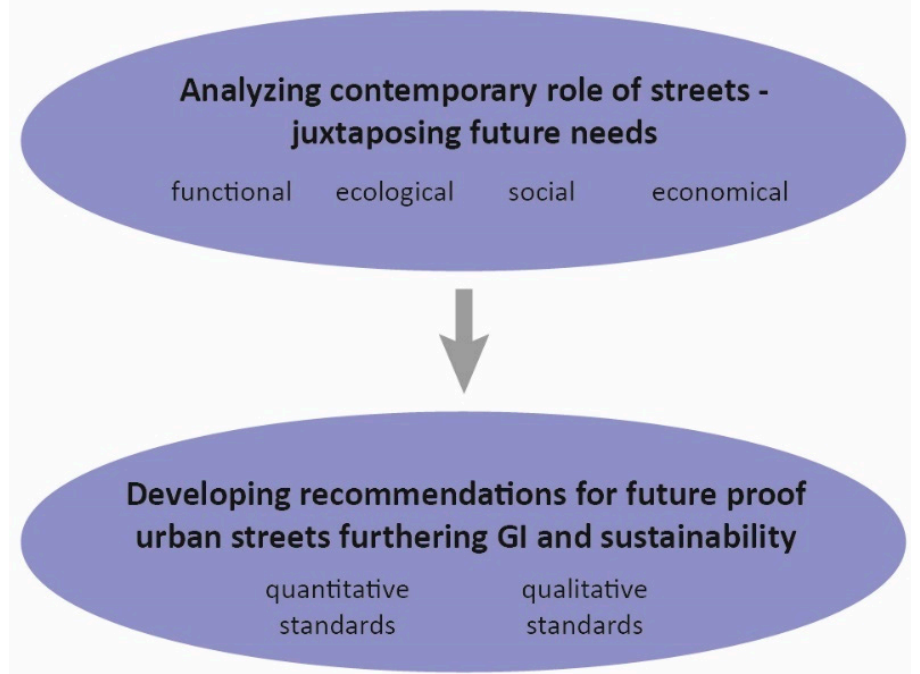

Figure 1. Research goal, schematic approach.

The paper will conclude by emphasising ways for a comprehensive consideration and redesign of streetscapes as one promising puzzle in the urban GI system to counteract evident challenges of climate change and the general lack of widely useable public space in urban settings. Its range reaches from small-scale microclimatic and social improvements up to citywide provision of accessible, useable, ecologically sound and sustainable public space.

The presented outcome builds on a transdisciplinary research study which was carried out in collaboration with and contracted by Vienna's planning administration, whereby the research team was composed of scholars (landscape architecture, BOKU Vienna and social work, FH Campus Vienna), and experts of the administrative body including urban planning and road construction. Practicing professionals and stakeholders contributed in collaborative workshops.

\section{Materials and Methods}

The study is based on a mixed-method approach (Figure 2). The research consists of literature work, an elaboration of empirical data and expert interviews, which together allow us to derive qualitative and quantitative aspects which need to be realised in order to create sustainable streets that serve as carriers of green infrastructure. The study examines public space in Vienna, particularly urban streets of all types. Highways and roads with heavy traffic that are not in the legal responsibility of Vienna City Administration were excluded. 


\section{Empirical research -} case studies

Inventory, spatial and functional analysis of Vienna streetscapes
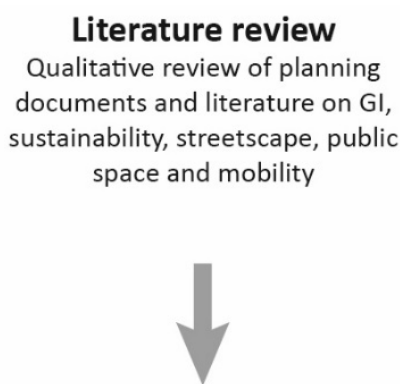

\author{
Expert Interviews \\ In depth interviews with \\ experts in planning and \\ administration
}
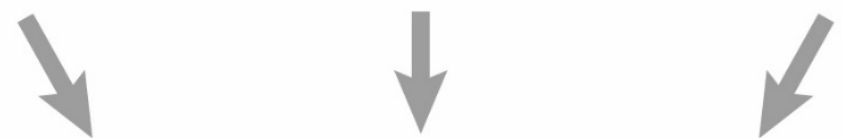

Extraction of qualitative and quantitative criteria

for sustainable future streets including the role as carrier of GI

Considering functional, ecological, social and economic issues

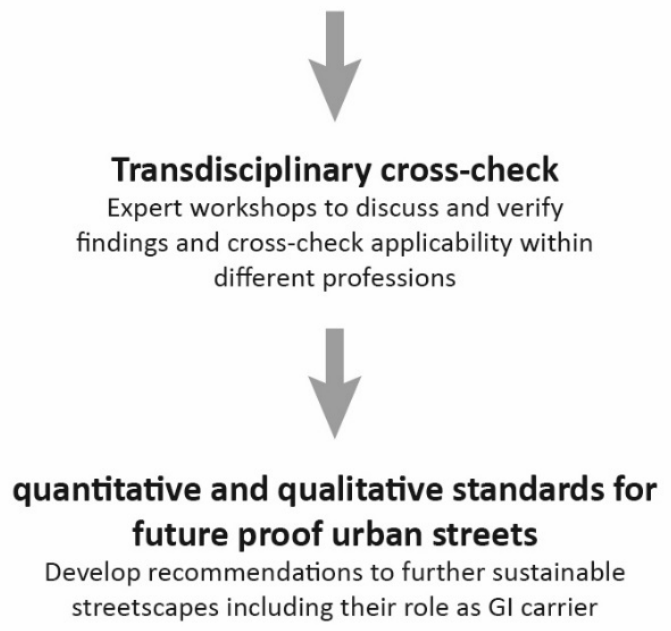

Figure 2. Research design.

As a starting point, the results of accomplished studies by the authors at the Institute of Landscape Architecture were supplemented by a qualitative literature review on specifications of public space and streets with regard to layout, distribution and functions. Sketched and described street sections were analysed to define a minimum space for non-motorised uses such as walking, biking (active mobility), but also for greening or other. The current role of streets as public spaces and carriers of GI was examined and compared with international definitions and recommendations. As sustainability and its social, ecological and economical aspects [32] are important arguments for the transformation of streets, it was given special consideration in the literature review. Further, a qualitative review of planning documents of European cities available in German or English was conducted to examine existing strategies in dealing with the topic. Thus, thematic concepts and municipal manuscripts were systematically scanned and qualitative and quantitative recommendations, as well as figures for spatial distribution of street space for different functions, were extracted. The review was completed for the cities Copenhagen, Munich, Zurich, Berlin, Barcelona, Rotterdam, Stockholm and Oslo. The cities were chosen due to conditions similar to Vienna, regarding population growth, density or inner-city densification processes and progressive planning strategies.

Before elaborating on new recommendations for Vienna's streets, the current availability of public space in different parts of the city was inventoried. Seven case studies of urban quarters of 11 to 19 hectares $\left(0.11\right.$ to $\left.0.19 \mathrm{~km}^{2}\right)$ were examined to compare new development areas such as Seestadt Aspern, Sonnwendviertel, Nordbahnhof, and Atzgersdorf with old city quarters built in the 19th and 20th century such as the 9th, 5th and the 18th district. Quantitative analyses were carried out on the basis of detailed sectoral mapping, providing information on the supply and proportion of available public spaces. Categories 
of space for motorised and space for non-motorised uses were documented to calculate an average for each city quarter. The share of different functions was extracted from datasets of open-source city maps $[33,34]$ and proceeded with AutoCAD and ArcGIS. Additional field research allowed us to counter-check digital findings and to clarify uncertainties.

Findings of our literature work and sectoral mapping of Viennese streets were combined and processed in two ways. First, the placement of streets within the discussion on sustainable development was elaborated, and second, recommendations for the future treatment of street space in Vienna were provided.

Building on and complementing these findings, six guided in-depth expert interviews were conducted. The interview partners were chosen from the field of architecture, spatial planning, landscape planning and urban planning. Aim of the interviews was to concretise existing knowledge, to close gaps and to integrate the perspective of different disciplines and actors involved in the planning of public spaces. Questions concerned influencing parameters, type and degree of detail of the recommendations, the role of the diversity of urban areas with regard to generally applicable recommendations, relationship between urban public spaces and green and open spaces as well as good practice examples. The interviews were audio-recorded, the answers structured and key findings extracted according to the research questions.

To submit the findings to a transdisciplinary cross-check, they were presented in two transdisciplinary workshops with experts and stakeholders. Structured discussion provided feedback, know-how and practical in-depth insights into the findings. In the workshops, experts' knowledge was collected and specified to be translated into recommendations.

\section{Results}

\subsection{Current Situation in Vienna}

In the following, we highlight how much of Vienna's public space is dedicated to which kind of function-in particular, motorised traffic and other uses in streetscapes.

Earlier findings show the spatial distribution in Vienna [12]. The average spatial distribution, calculated from 10 exemplary pilot streets, represents the dominance of car use by two-thirds within an average Viennese street (Figure 3). Other cities, such as Rotterdam or Copenhagen, dedicate a larger share to active mobility, namely up to 50 percent [12]. The average layout, again calculated from 10 comparable streets in each city, make differences in the built environment obvious (Figure 4). While Copenhagen provides continuous bicycle infrastructure as well as trees in more than half of the streets investigated, Vienna is dominated by cars.
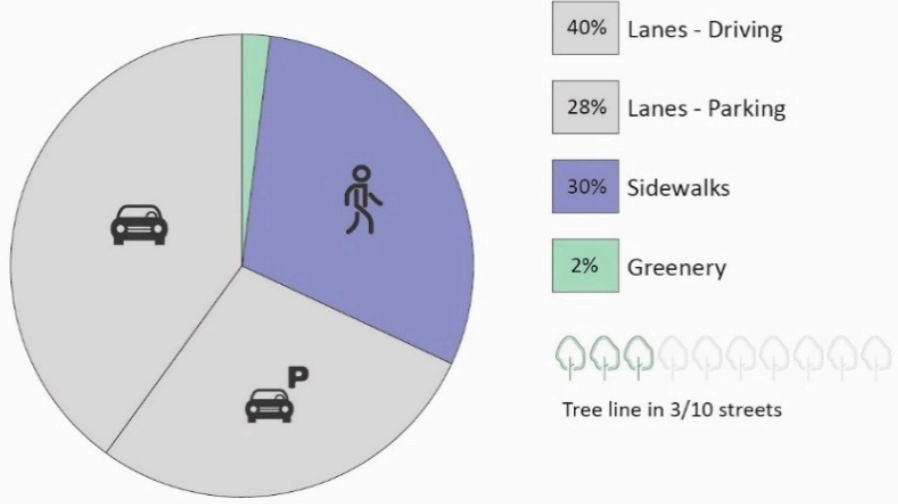

Figure 3. Average spatial distribution in Viennese streets calculated of 10 cases. Cars predominantly occupy space for driving and parking. 

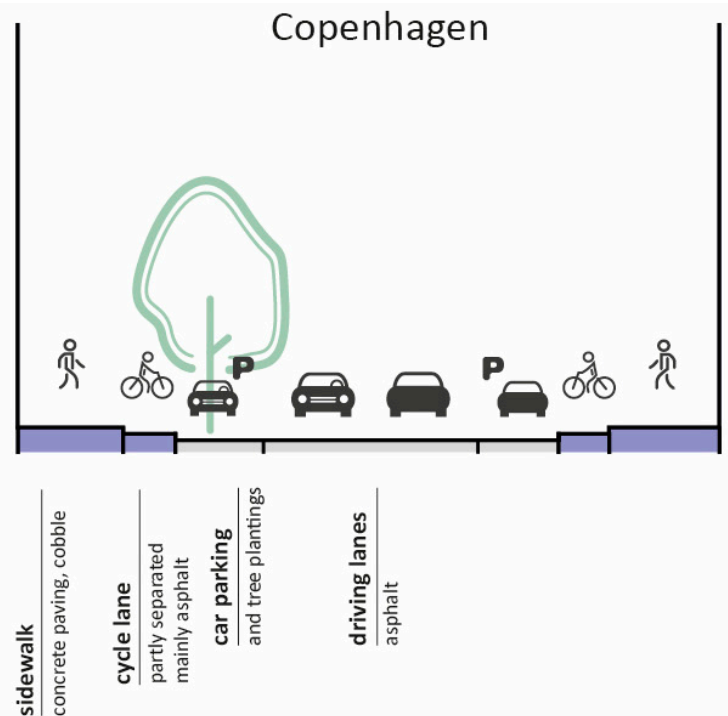

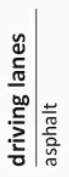

(a)
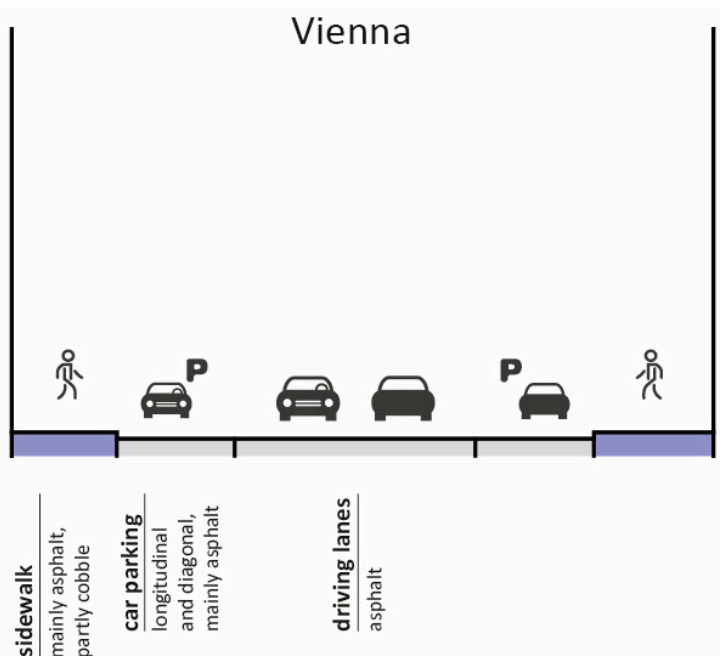

(b)

Figure 4. Structural differences between cities are shown by average layouts, calculated from 10 streets in each city. (a) While Copenhagen provides continuous bicycle infrastructure as well as trees in more than half of the streets investigated, (b) Vienna is dominated by cars.

However, case studies within this study in seven Viennese areas show that the availability of public space for non-motorised uses in current Viennese development areas looks more promising than in old quarters (Table 1 and Figure 5). Whereas on average two-thirds of public space is reserved for cars in old city quarters, in newly built areas only between 34 and 54 percent of public space is used for motorised car traffic (consisting of driving lanes and on-surface parking).

Table 1. The table shows a summary of available public space in examples of several Viennese districts. It includes city development areas of recent years (1-4) and built-up areas from the 19th/20th century (5-7). Green spaces (parks) are not considered in the calculation on available hard surface public space. The figures show the unbalanced spatial provision of public space in favour of motorised traffic, especially in old city quarters. In new development sites this value is more balanced and offers more public space for sustainable, non-motorised and green uses.

\begin{tabular}{|c|c|c|c|c|c|c|c|}
\hline & $\begin{array}{c}\text { Vienna Survey } \\
\text { Areas }\end{array}$ & $\begin{array}{l}\text { Total Survey } \\
\text { Area in } \mathbf{m}^{2}\end{array}$ & $\begin{array}{l}\text { Public Space } \\
\text { (Streets, } \\
\text { Squares) in } \mathrm{m}^{2}\end{array}$ & $\begin{array}{l}\text { Space for } \\
\text { Motorised } \\
\text { Uses } \mathbf{m}^{2}\end{array}$ & $\begin{array}{l}\text { Space for } \\
\text { Motorised } \\
\text { Uses \% }\end{array}$ & $\begin{array}{l}\text { Space for Non- } \\
\text { Motorised } \\
\text { Uses } \mathrm{m}^{2}\end{array}$ & $\begin{array}{l}\text { Space for Non- } \\
\text { Motorised } \\
\text { Uses \% }\end{array}$ \\
\hline 1 & $\begin{array}{l}\text { Seestadt Aspern, } \\
\text { 22nd district }\end{array}$ & 121,000 & 49,500 & 17,000 & $34 \%$ & 32,500 & $66 \%$ \\
\hline 2 & $\begin{array}{l}\text { Sonnwendviertel, } \\
\text { 10th district }\end{array}$ & 156,000 & 60,000 & 32,500 & $54 \%$ & 27,500 & $46 \%$ \\
\hline 3 & $\begin{array}{l}\text { Nordbahnhof, 2nd } \\
\text { district }\end{array}$ & 150,000 & 55,000 & 27,500 & $50 \%$ & 27,500 & $50 \%$ \\
\hline 4 & $\begin{array}{l}\text { Carré Atzgersdorf, } \\
\text { 23rd district }\end{array}$ & 110,000 & 37,500 & 13,000 & $35 \%$ & 24,500 & $65 \%$ \\
\hline 5 & $\begin{array}{c}\text { Margareten, } 5 \text { th } \\
\text { district (old quarter) }\end{array}$ & 190,000 & 42,500 & 25,000 & $59 \%$ & 17,500 & $41 \%$ \\
\hline 6 & $\begin{array}{l}\text { Servitenviertel, 9th } \\
\text { district (old quarter) }\end{array}$ & 180,000 & 48,000 & 28,000 & $58 \%$ & 20,000 & $42 \%$ \\
\hline 7 & $\begin{array}{c}\text { Währing, 18th } \\
\text { district (old quarter) }\end{array}$ & 147,000 & 36,500 & 24,000 & $66 \%$ & 12,500 & $34 \%$ \\
\hline
\end{tabular}



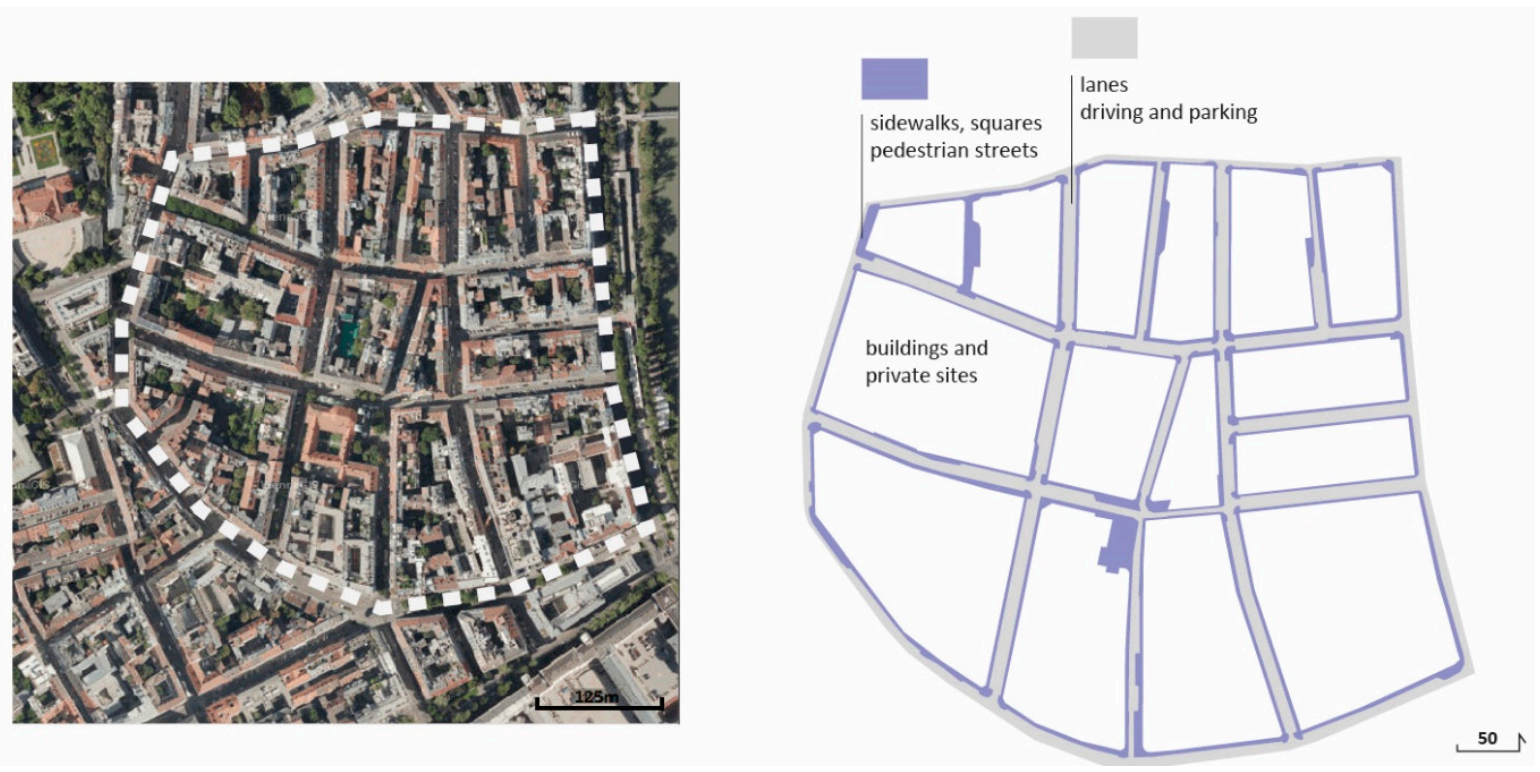

Figure 5. Structural example for mapping of an old neighbourhood in Vienna: Servitenviertel, a quarter in the 9th district of Vienna. Almost $60 \%$ of public space is reserved for motorised car traffic, consisting of driving lanes and on-surface parking; $40 \%$ is available for pedestrians (sidewalks, pedestrian streets, small squares, greenery).

\subsection{Sustainable Streets: Functional, Ecological, Social and Economic Soundness}

In this section we present results from reviewed literature, planning documents and relevant studies.

Streets can be seen as linear urban open spaces which require a set of properties to achieve the goal of sustainable development, namely meeting today's needs without limiting future ones [35]. The review focuses on functional, ecological, social and economic aspects which determine the streets' role as a sustainable public open space. Their limited surface from façade to façade has to accommodate all these qualities in a good balance which allows for flexible use. Recommendations are defined based on these findings (Section 3.4).

From a functional perspective, streets provide public access to buildings and facilities. They structure and order the built-up area and run as a network through the entire city. Streets are carriers of visible and invisible infrastructure elements such as pipes and sewers below the surface that are essential for the daily functioning of the city. Beyond carrying technical infrastructure, streets are spaces for movement of people and goods. Sustainable forms of transport, such as walking, cycling, shared, intermodal and public transport consume fewer resources and affect the environment significantly less than motorised individual modes of transport. Walking or biking are even non-polluting activities and therefore help to reduce particle pollution and carbon emissions [1,20,36,37]. Furthermore, cars occupy 10 times more space for movement, as well as for parking, than bicycles. In order to encourage a more balanced distribution between users and to foster sustainable/active forms of movement, progressive administrations such as Rotterdam or Copenhagen have gone back to emphasising the use of streets for pedestrians and cyclists, where active (i.e., non-motorised) mobility is allowed to occupy up to half of the surface [12].

The National Association of City Transportation Officials [4] suggests to flip the socalled planning pyramid and give priority to pedestrians, cyclists, as well as lingering, playing or green spaces, followed by public transport. Individual car traffic then comes last. Planning principles that meet human needs and make non-motorised uses inviting must be applied [19,36,38-41]. As a consequence, streets are no longer treated as traffic spaces considered from an efficiency point of view to get from $A$ to $B$ as fast as possible, but as a quality space situated between A and B. It is not only transport space but a true public 
space in its entirety, including its contribution to green infrastructure $[17,20,21,42]$. This goes hand in hand with rethinking the car-centred layout.

From an ecological perspective, streets are relevant as carriers of flora and fauna. Beyond greening, water and the perspective of blue-green infrastructure in a "water sensitive city" [43] (p. 46) where urban planning incorporates aspects of water management to ensure a network of green systems for rainwater harvesting [43] has become a frequent feature of contemporary street planning in Europe since the beginning of the 2000s. This means GI and connected planning measures take the hydrological cycle into account, as GI "facilitates the infiltration and storage of water in soils and the release of water back into the air through transpiration" [9] (p. 92). Thus, permeable surfaces, vegetated streets, swales and tree pits capture rainwater that would otherwise run over impermeable surfaces into the sewer [9]. However, there are examples of swales being put in alongside streets to catch run-off that date back to the 1990s. Dunnett and Clayden [44], among others, have advocated so-called rain gardens, showing numerous examples, including the collection of rainwater run-off from the street surface and applying permeable paving and surfaces [4,45-47].

Prompted by more extreme rainfall events caused by climate change, cities specifically address the problem of rainwater run-off from sealed surfaces such as streets. In addition, streets form vast non-absorbent surfaces contributing significantly to the urban heat island (UHI) effect. Given the heat-storage capacity of such surfaces, unshaded roads and parking lots can raise the surrounding air temperature by $11-22{ }^{\circ} \mathrm{C}$. This makes the environment hotter, affecting people's health, and increases power consumption to cool buildings [1]. Green infrastructure can decrease the absorption of radiation by surfaces, the release of pollutants, and also cools the air through evapotranspiration.

Breaking down GI to street level, it is essential to consider the structure and impact of GI in an urban setting. It is a systemic way of thinking about how the totality of components works together, which consist of patches and corridors, where corridors ideally connect patches to one another, forming matrices. "A higher quality matrix consists of a connected structure of patches and corridors. Conversely, a matrix of lower quality consists of isolated patches" [9] (p. 16). As built environments often cut off small patches of green space from one another, it is the potential of streets to be transformed into such greened corridors. As streets are, per definition, longitudinal spaces, linear connections form a complete network of open spaces covering the whole city and thereby creating a perfect carrier of urban GI composed with trees, shrubs, vegetated swales and permeable surfaces.

Even currently sealed and built-up surfaces can become part of the green infrastructure through unsealing, greening and planting trees. This requires the availability of sufficient and appropriate space, which often necessitates a redistribution of road space. Only about $2 \%$ of Vienna's average street space is used for greening (Figure 3). Additionally, the comparison of Vienna-Copenhagen (Figure 4) demonstrates that there is room for improvement.

Stockholm, Rotterdam, Oslo and Copenhagen, among other cities, explicitly demand a progressive reinterpretation of a street's role against climate change in their planning documents [48-53]. Pilot sites such as Oslos Deichmans gate (Figure 6) or the Østerbro Quarter in Copenhagen are evolving; the latter is even called Copenhagen's first climate-resilient neighbourhood $[43,49]$, where green streets, green urban squares, and cloudburst streets that divert rainwater away from the neighbourhood have been realised. The ambitious goal is to use green and blue solutions to disconnect $30 \%$ of the rainwater from the sewers in the Climate Resilient Neighbourhood. These solutions are promoted as cheaper, easier, and more flexible than conventional solutions of rainwater runoff into sewers and bring benefit as more inviting public space with greener streets and improved urban space $[49,53]$.

The Environment Programme 2020-2023 of the City of Stockholm breaks it down to two milestones: Improved ability to cope with effects of torrential rain and improved ability to cope with effects of heat waves. Both referring, inter alia, to a transformation of streets, demanding multifunctional surfaces to "ensure sustainable stormwater manage- 
ment through, for example, green roofs and permeable coverings, as well as plant beds and skeletal soils with trees in the urban environment." [50] (p. 19). Advanced cities as stated above take the entire open space into account, knitting the network of streets into squares, playgrounds, green areas, and water spaces.

Additionally, the city of Vienna increasingly relies on an enhanced version of the "Stockholm principle" for the sponge city concept of collecting and percolating rainwater on several pilot sites (Figure 7). The concept provides greened roads and permeable surfaces to capture rainwater that would otherwise be led into sewers. As a technical effect, the amount of run-off is reduced and sewers are less overloaded [9,54]. It consists of a dual collection system: surface run-off is collected in sewers along the paved surface, and planted swales provide space for percolation $[44,55]$. These adaptations are particularly responsive to rising temperatures due to climate change and resulting urban heat islands.

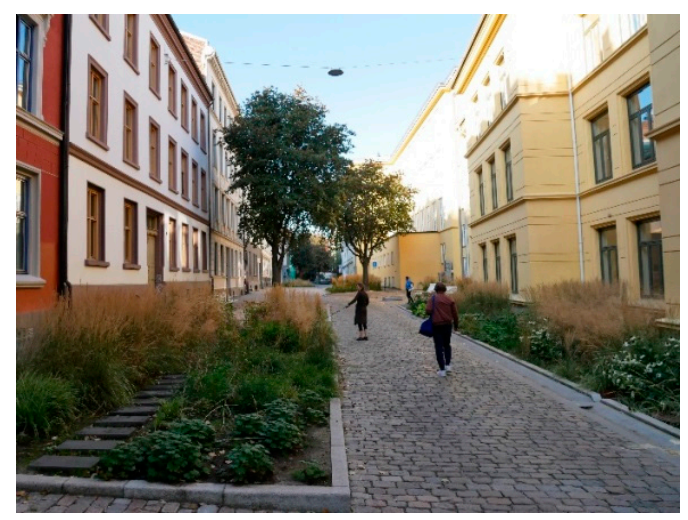

Figure 6. Redesign of Deichmans gate in Oslo. The European Green Capital 2019 is transforming its public space within its Car-free Livability Programme. Streets are main part of this transformation. Greened beds are made to capture with rainwater runoff, absorb and retain it and evaporate it, additionally producing a cooling benefit for the surrounding. OFurchtlehner.

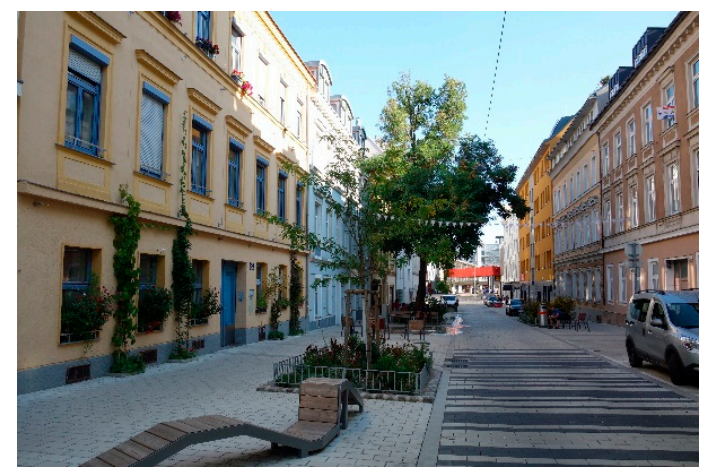

Figure 7. Vienna, Pelzgasse. Publicly useable and multifunctional space for residents and green infrastructure, following the sponge city concept: rainwater is led to planted beds, stored, filtered and percolated. $\odot$ Furchtlehner.

Streets are also place for communication and social exchange and therefore connected to the social dimension of sustainability. The inevitable public character, which generally implies public (and free) accessibility at all times, is noteworthy. Streets have always been meeting places and spaces of social expression and social as well as societal/political representation and identity $[19,40,45,56]$. People identify themselves with streets and occasionally they offer space for appropriation. Mehta [19] calls a sociable street a street that supports active and passive activities and behaviours. Gehl differentiates within the use of streets between necessary activities, which include transport or other movements from one place to another, and optional and social activities such as spending leisure time 
and interacting. The latter is enhanced by pleasant surroundings, meeting the expectations of different user groups [36,57].

Again, the aspect of GI is interwoven. Surveys have consistently highlighted that trees and other plants are the most important attractors for streets, while their absence is perceived as the most negative aspect $[11,58]$. When asking about satisfaction with public and green spaces in a broad Viennese survey, traffic calming measures, more accessible green in the surrounding and better useable public space are highly demanded, especially in dense city quarters $[10,59]$.

Streets have the potential to satisfy these demands while keeping their necessary transport function. Again, a spatial redistribution of street space is key in adjusting. Allocating space from car traffic is thereby justified by social, health, environmental and economic benefits, as Gössling [37] argues from different perspectives. Additionally, roads transformed into GI can contribute to more equitable distribution of green space. A considerable body of literature has provided evidence that resources such as parks are not always equitably distributed across communities. The accessibility of urban green spaces is usually strongly dependent on socio-economic factors such as ethnicity, income, or age [60-62]; "Thus, inequities in the distribution of public resources are also environmental justice struggles, and differential access to urban public facilities that privileges one group and disadvantages another may also constitute environmental injustice" [62] (p. 231). As part of the green infrastructure, streets can help to boost the supply of accessible green spaces on a neighbourhood scale. Streets therefore play a major role in completing green networks and can help to diminish unequal distribution of green $[9,63]$. Designing streets that give non-drivers a fair share of road space theoretically makes streets more equitable. This is notable due to the circumstance that $20-40 \%$ of residents cannot or should not drive due to physical impairment, poverty or age [64]. In the case of Vienna, $45 \%$ of households do not own a car [65]. As design and spatial distribution can support activities, it is notable that individual appropriation and perception of using streets depends on various factors such as cultural or socio-economical background and local conditions [19]. However, basic planning principles and shaping a resilient and inviting framework may work globally $[4,17,45]$.

Further, sustainability includes economic aspects. The economic utilisation of streets involves the use of street space as location for outdoor areas of restaurants, markets, kiosks, vendors or advertising installations. Some of these uses in the street space may fulfil an important social function as a meeting point and place of communication. They convey urban vibrancy and can support the subjective feeling of safety (i.e., through the presence of people, busyness, and lighting). At the same time, these economic uses compete for available space with other (non-commercial) demands, such as the effort to transform roads into green infrastructure. Using the street for the purpose of economic exploitation is based on the question of who is granted the space and who or which other uses are pushed out. In the spirit of sustainable development, with its promise to satisfy human needs and aspirations, it is necessary to leave sufficient space free for non-commercial uses. Therefore, city administration and politics have to ensure a balance between commercial and non-commercial uses and activities in order to preserve the public character of the street space [66-68]. Providing specific zones or guidance for the placement of economic interventions and to gain money out of it for public services may be a possible way to handle the issue. Many cities, including Vienna, have such regulations which are discussed in another article by the author [67]. Economic aspects include many other topics, such as material or maintenance costs but also values, as a location factor. However, these were not considered in the course of this project.

As presented and proved by various authors $[17,19,36,68,69]$, special focus in any street-related consideration has to be put on the edge zone along the building facades, as this space defines public space and is the connection between ground floor and street space, often between private and public. It is predestined for (social and commercial) interaction and appropriation. Being transparent, diverse, and well structured, an active ground floor 
improves the quality of the adjacent street and how it is perceived. The edge zone can be used for greening, for economic purposes such as window shopping or vendors, but also for social appropriation of private and commercial uses such as sidewalk cafes or informal seating in front of the buildings, thus making streets more inviting and characteristic and promoting walking or cycling $[19,36,68,69]$. Another adjustment in favour of a living quality and safety for all user groups lies in reducing car speed [4] due to design measures but primarily on the basis of legal frameworks.

\subsection{The Experts' Point of View}

All conducted in-depth expert interviews confirmed and strengthened findings from literature or outlined additional aspects of relevance, summarised as qualitative and quantitative aspects below.

Streets should be considered and planned as a fully fledged public space to enable qualities beyond a pure traffic function. This emerged understanding of the potential of the street to serve as a public space can be seen as state of the art within experts of all included disciplines. Single interview partners pleaded for very detailed recommendations in order to deliver a tight framework, whereas the majority preferred a broader framework that leaves room for adaption in all planning stages. The definition of qualitative and quantitative minimum standards should be valid for new street construction but also be possible to transfer to an existing street network if needed.

Experts' statements on qualitative aspects: All experts were in favour of significantly more greening and ecological climate-friendly design, respectively, fostering environmentally friendly and active mobility. This has to be a topmost goal. Strengthening these aspects through design measures (such as rainwater management, use of materials, greenery, furnishing) and a balanced spatial distribution to this effect was named by all interviewed experts. Several experts pleaded to include neighbouring social institutions in the design considerations; however, the main focus has to be set on flexible, resilient and robust public space that allows various appropriation by all user groups and that is apt to changing demographic situations. Suitability for everyday use is named to be highly important.

Additionally, a mix of different-sized public squares alongside the streets network has been suggested to complement the puzzle of public space, as it is promoted in already existing municipal documents. Additionally, the strong connection between ground floor usage of buildings and street space was named several times as an important aspect in developing a futureproof and inviting public space. This interaction has to be treated in a wider context, as this vitality is linked to the overall urban structure. However, aspects such as the provision of sufficient adjacent public space to buildings and its usability for appropriation, social interaction or economic purpose may be supporting.

Experts' statements on quantitative parameter: Besides qualitative aspects, experts called for numbers and quantitative parameters - such as percentages, square meters or other figures - to work with. Those are useful to provide and safeguard minimum areas in public space for all user groups and GI. As such numbers already exist for green spaces such as parks in Vienna ( $\mathrm{m}^{2} /$ person), a similar approach should be thought of for useable hard surface public space; however, a direct transfer seems difficult.

\subsection{Quantitative and Qualitative Recommendations for Sustainable Streets in Vienna}

Given the manifold demands on future street space described in previous chapters, a redistribution and rethinking of available space is inevitable in order to become an interwoven part of a city's GI network and an inviting sustainable public space. In the collaborative setting of the study, the following claims were elaborated:

\subsubsection{Spatial Provision of 50\% of Public Space for Non-Motorised Uses and Greening}

As the main recommendation resulting from the elaboration process, interviews, workshops, literature [4,68,70-72] and previous findings by the authors [12], at least 50\% of each street section has to be provided for non-motorised uses and greening measures (Figures 8 
and 9). This quantitative recommendation is valid as a base for all street typologies in new development areas, such as neighbourhood streets or shopping streets, but can also be used for redesigning streets in built up existing areas. Exceptions are shared-space streets, pedestrian or bicycle streets, or streets with a width of less than $12 \mathrm{~m}$ as well as streets with separated lanes for public transport. Highways and roads with high traffic volumes that are legally not in the responsibility of Vienna City Administration are also excluded from these calculations.

minimum

$50 \%$ for non-motorised uses

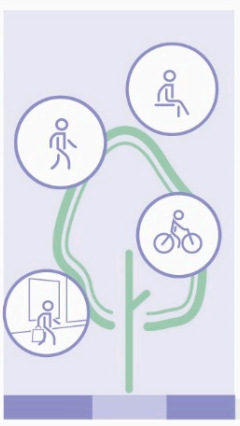

$\geq 25 \%$
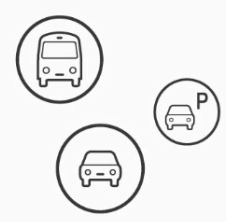

$\leq 50 \%$

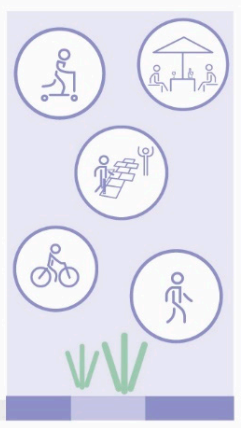

$\geq 25 \%$

Figure 8. Quantitative distribution key for public spaces. The schematic diagram of a representative cross-section shows that at least $50 \%$ of the street layout should be available for non-motorised uses and greening. Different configurations are possible as long as percentage is ensured.

$>50 \%$ space for greening and

$\leq 50 \%$ space for motorised uses non-motorised uses

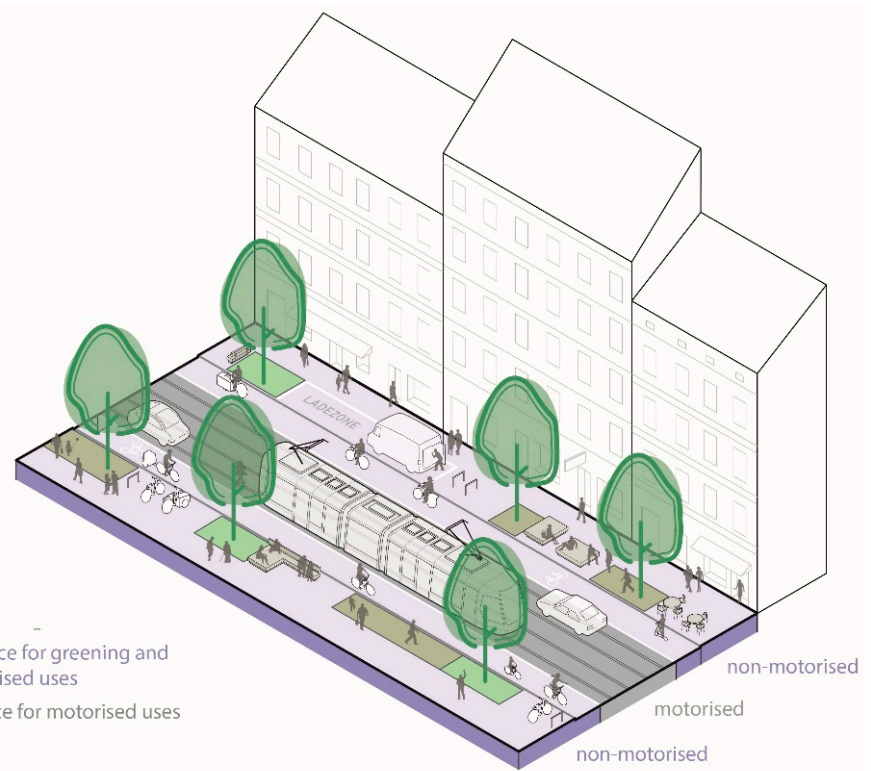

Figure 9. Possible translation of the recommendations to a Viennese commercial street. It is implementing the strived $50 \%$ criteria for non-motorised uses and serves as carrier of green infrastructure. Trees, vegetation, and permeable surfaces are an important part of the setting.

The recommended minimum 50\% space for non-motorised uses include sidewalks, curb extensions, cycle lanes (preferred built as separated bike lane), multifunctional and furnishing zones with space to sojourn, sport or play, and it includes space for greening in form of planting beds, swales and street trees. Austrian manuals and guidelines state that sidewalk width must not fall below $2 \mathrm{~m}$ at any point (minimum passage width) so that people can pass each other even with strollers or wheelchairs [73-76]. However, $2.5 \mathrm{~m}$ and upwards are internationally recommended to be used as the new standard to offer space for additional activities $[4,68,75]$. 


\subsubsection{Safe and Inviting Design and Furnishing}

Widely approved general demands such as barrier-free crossings or sufficient lighting have to be available. Those design standards are already defined in existing Viennese documents such as the Viennese Thematic Concept Public space [66] and are strongly recommended by the authors in order to create safe and accessible, inviting and enjoyable surroundings allowing for different uses. A matrix offering qualitative aspects based on Jan Gehl's guidelines for public space has been adapted for Vienna and serves as foundation $[36,72]$. Streets have to fulfil a series of criteria derived from the previously mentioned standards. The more a street is considered to become a "place" instead of transit space, the more features are recommended. Those include opportunities to walk without obstacles on good and barrier-free paving and crossings, enjoyable opportunities to sit and stay including equipment for all ages, lighting, water features at regular intervals but also providing multifunctional and flexible space for appropriation, playing or exercising. Spatial aspects such as shading and configuration of placement should be included. On the other hand, design measures to lower traffic speed are to be applied situationally. The same applies to providing and integrating sufficient space for delivery and the like. These aspects have to be considered within the whole planning process and also include design aspects which are part of detailed planning at a later planning stage.

\subsubsection{Vegetation and Permeable Surfaces}

In addition, and to promote the ecological aspect of a sustainable street, we recommend climate approved trees be planted alongside all streets. If not possible due to structural reasons or grey infrastructure such as pipes below the surface, trees have to be planted at street crossings as there is more space available. Only that ensures a connected green network. Permeable surfaces are to be installed regularly alongside the streets and the approved sponge city concept to capture and store rainwater has to be considered as comprehensively as possible with regard to local conditions. The system can be seen as one milestone towards a green and blue street infrastructure.

\subsubsection{Micro-Open Spaces}

Micro-open spaces such as small squares which include (natural) shadow and space for sojourn contribute to the ecological and social aspect of streets. A micro-open space at least every $200 \mathrm{~m}$ is suggested, with a special focus on making crossings and corners as comfortable and safe as possible for non-motorised user groups. In literature, a $200 \mathrm{~m}$ distance is recommended and described as a valid and reasonable figure [72,76]. An adult needs about $2 \mathrm{~min}$ for this distance and it is equivalent to the recommended distance between bus stops in dense urban settings [70]. This consequently means that every resident can reach one of those sites less than $100 \mathrm{~m}$ from their home in most cases. Such micro-open spaces can also be placed alongside streets as parklets (reuse of parking lot for temporary greening and sojourn) or within building setbacks $[21,54,77]$, considering local conditions and requirements [19].

\subsubsection{Considering Public Institutions and Space for Appropriation and Adaption}

According to the social component of a sustainable street, the team further recommends adjusting the street equipment in the vicinity of an institutional facility (school, hospital, kindergarten, retirement home, municipal building): within a radius of $250 \mathrm{~m}$, the user group or the function should be considered in the design of public space and its amenities. The chosen radius represents the catchment of a living or working surrounding in a neighbourhood, which is also used in previous documents of the Vienna City administration $[28,72,78]$. In addition to the specific needs of public institutions, the authors advocate providing sufficient flexible space for later changes and adaptations. Space without programming is also important for individual appropriation [40]. 


\subsubsection{Network of Squares to Complement Green Streets}

In defined new city development areas that exceed 800 residential units, in addition to the street recommendations named above, a network of different squares has to be established. This includes micro-open spaces every $200 \mathrm{~m}$ along streets as stated, but also neighbourhood squares (Nachbarschaftsplatz) every $500 \mathrm{~m}$ as well as district squares (Stadtteilplatz) with higher relevance and more offerings every $1000 \mathrm{~m}$. Figures were extracted from literature and planning documents, compared and discussed in expert workshops. As similar numbers exist for green spaces on different city levels and as experts claim that these numbers have worked for green spaces, they were transposed to public spaces $[26-28,72,78,79]$. Distance recommendations go along with a reachability within walking distance of 5-15 $\mathrm{min}[31,76]$.

\subsubsection{Vital Edge Zone and Space for Commercial and Non-Commercial Uses}

As there is a close correlation between the ground floor level of buildings and the adjacent public space, this edge zone has to be considered case by case and be well integrated and coordinated in any street planning. Accessibility has to be provided and monotonous facades are to be avoided. Interventions alongside the facades should be easily permitted as far as there is a sufficient passage width left on the sidewalk. This can be private interventions and appropriation such as (façade) greening or informal sitting but also furnishing in front of shops or restaurants.

Sidewalk cafes, kiosks and the like can serve as an important feature in public spaces and are to be supported. However, a balance between commercial and non-commercial uses and furnishing has to be safeguarded within the whole planning process. Existing Viennese regulations for the placement and design of such interventions are to be adhered [67,80]. A summarizing table (Table 2) lists all of these recommendations.

In addition to the standards for streets, the overall spatial distribution within public space in a defined development quarter is relevant. As we recommend, at least $60 \%$ of all hard surface public space has to be primarily dedicated to non-motorised uses such as sidewalks, bicycle lanes, pedestrian streets or squares combined with greening (Figure 10). This number is related to recent development areas in Vienna (see also Table 1, last column). Its derivation is based on the average from inventoried development areas. The proposed figure has been discussed and approved in experts' workshops and is intended to be applied when developing new city quarters.

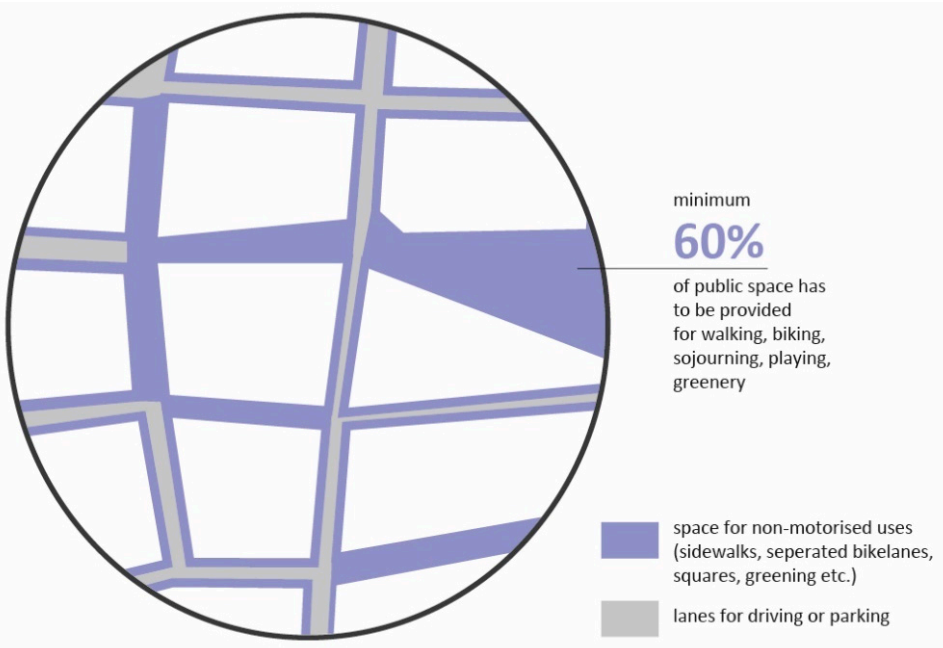

Figure 10. Schematic illustration, minimum $60 \%$ of all hard-surface public space in new development areas has to be dedicated for non-motorised uses and greening, consisting of sidewalks, pedestrian streets, bicycle lanes, squares or the like. 
Table 2. Summary of recommendations for new standards of futureproof streets in Vienna-evolved from general considerations of sustainable streetscapes.

Sustainable Streets-General Summarising Considerations

Recommendations for Vienna

Streets as quality public space

Streets as GI;

Functional Aspects Accessibility and safe movement, fostering environmentally friendly, non-motorised and public transport modes

Streets as a component of GI network

carriers of flora and fauna;

Rainwater management

Enabling optional and social activities;

Room for appropriation;

Social aspects Accessibility;

Ground-floor interaction;

Identification/neighbourhood

Economic aspects
- $\quad$ Minimum $50 \%$ of street space for non-motorised uses and greening (sidewalks, cycle lanes, space for further activities, vegetation)

- $\quad$ Safe and inviting design and furnishing including lighting, public seating, water features and shadow at regular intervals; barrier-free and safe layout and accessibility

- Vegetation and permeable surfaces, climate-proof trees alongside each street, street crossings with green elements; use of permeable surfaces and planting beds to mitigate UHI, enabling of rainwater management such as sponge-city concept;

- $\quad$ Greened micro-open spaces every $200 \mathrm{~m}$

- $\quad$ Sufficient space for activities and appropriation

- Considering public institutions and local conditions

- $\quad$ Network of squares to complement green streets and micro-open spaces: Neighborhood squares every 500 $\mathrm{m}$ and district squares every $1000 \mathrm{~m}$

- Vital edge zone, adjust and support of interaction with ground floor of adjacent buildings and alongside facades, private greening and furnishing

- $\quad$ Space for commercial and non-commercial uses, provision of space for commercial uses in public space on specific places; safeguard balance between commercial and non-commercial uses (sidewalk cafés vs. public seating) and preserve public character of streets 


\section{Discussion}

This paper comprises the results of a literature review, including planning documents of international examples and the findings of empirical quantitative and qualitative analyses of street sections. It is focused on the ability of streets to carry green infrastructure and presents results for the city of Vienna elaborated as planning recommendations.

According to international literature, we base the transformation of streets on a "sustainable development approach, fulfilling a variety of environmental, social, and economic objectives" [14] (p. 18). The body of literature on these topics is also reflected in the recommendations for Vienna, which focus on functional, environmental, social and economic aspects of streets. The literature review reveals that encouraging projects have begun to be realized in recent years in many cities $[20,40,46,54,81]$ in a way to cover both a street's movement function and also its ecological and place function [42]. They are no longer planned mainly for cars, but also as a place to serve people's need for social and optional activity [36].

The paper elaborates on the question of how to distribute and design the available space, reaching for a futureproof urban setting. This may increase the variety of possible uses and activities within the streets on the one hand and elaborates on the question of how streets can be set up in order to function as carrier of GI.

As our study confirms, at present, streets in Vienna are neither designed and perceived as GI nor as part of an inviting sustainable public space-on average, they do not have the necessary spatial distribution to fulfil the multiple functions of a sustainable green street, as shown in the section analyses. On average, only $2 \%$ of the street share is allocated to greenery in Vienna and only 3 out of 10 streets are planted with trees [12]. This confirms our assumption that streets in Vienna do not realise their potential as carriers of GI. Layout comparisons of average street sections also reveal the little space dedicated for anything other than car-related use. The results are supported by representative surveys that prove the residents' claim for greener neighbourhoods in many parts of Vienna. This goes hand in hand with their demand for traffic-calming measures [59]. The mapping of increasing UHI in Vienna underpins an urge for action [82].

The recommendations elaborated in the course of our study contribute to the future treatment of streets in order to meet the requirements of a multifunctional sustainable street space. They are developed as minimum requirements and can be applied to nearly all urban street typologies. They are not binding, but serve as a basis for discussion in Vienna's municipal departments as well as a theoretical foundation for future decision making and should be implemented in planning documents as a next step.

The application of these recommendations at the beginning of a planning process in urban development areas safeguards sufficient quality and quantity at an early stage, but the content is equally relevant in later planning stages. Although primarily set up for city development areas, the recommendations have validity in older and already built up parts of the city likewise. Here, existing streets may be transformed-for example, within the scope of renovation works as recent examples in Vienna show (Figure 7) [40,54].

In the context of the spatial (re)distribution of street space, quantification appeared crucial as a basic requirement to enable functions beyond traffic. In Vienna, such key measures had only existed for green spaces. No specific citywide guidance for streets covered those requirements consistently. As explained in Section 3.4, the proposed quantitative parameter to dedicate at least $50 \%$ of the street space to non-motorised uses is primarily seen as an instrument to secure minimum areas, complemented by qualitative parameters that are building on existing Viennese and international guidelines and recommendations from literature. Since the question tackled in this paper is the aptitude of the street as a network for GI, the layout, organisation and design of the actual street is relevant in order to provide space for trees and greenery. As a minimum share of the street section of $50 \%$ has to be dedicated to non-motorised uses, this can then provide space for permeable or greened surfaces and planting trees. As GI is dependent on spatial continuity and connectedness, which streets do offer, the comprehensive transformation will contribute to green-space 
equity $[9,63,83]$. Since social equity is to be strived for and improvements of existing streets may contribute to green-space equity, it may also lead to gentrification processes $[84,85]$. Thus, a step-by-step application has to be intended city-wide, starting in areas suffering most from the lack of green and public space. The ubiquity of streets in urban settings holds the potential to tackle this challenge. However, the aspect of gentrification needs consideration in the broader discourse.

Due to the complexity of streets within planning responsibilities and a high number of stakeholders (traffic planning and engineering, city planning, architecture, greening department, public transport and emergency services and many others in Vienna [72,81]), transdisciplinarity and a clear structure are required. Hereby the recommendations are developed to be used as a framework which defines the corner stones for general standards for high quality and sufficient space. Adaptations are recommended according to the genius loci of every single situation [17].

A limitation of this study is that it did not elaborate on how to implement these recommendations in practice and if they truly fulfil their aim. Further research on the implementation and its impact is needed here. A trial period is planned by the city of Vienna that may deliver new cognition for adjustment if needed. It is planned to develop standard sections of distinct types of urban roads to illustrate how the design recommendations presented in this paper can be applied-for example primary roads serving motorised private transport and public transport, commercial roads, local roads and others. An example of such a translation is shown in Figure 9. Other relevant aspects of sustainability such as materiality, production and longevity of materials or specific plant selection are not considered in this study; nor are participation and maintenance. Those need further exploration.

Design aspects and provision of sufficient space are, however, only one step on the transition from the street as a traffic space to a green living space; further significant steps become relevant. One is the change in people's association and perception of streets as a result of established car-dependent habits and lifestyles. Another step is the legal frameworks and regulations which influence the behaviour and the future use of streets $[37,83]$. A transformational process of streets cannot be seen isolated. It has to be further supported by inviting alternatives to car dependency such as a well-functioning, city-wide public transport system, sharing opportunities, an inviting bicycle infrastructure and not least a comfortable and functional walking atmosphere. The benefits of greenery need to be transported and planning strategies such as "Stadt der kurzen Wege" or "15-minute city" which strive for a mixed urban fabric can be seen as the structural backbone.

\section{Conclusions}

Streets are coming more and more into focus as a multifunctional public space and carrier of GI as intrinsic structure in urban settings. Densification processes in many cities, as well as climate adaption, demand new approaches. Thus, the spatial potential of streets is being increasingly recognised by scholars and city administrations as streets are ubiquitous in the fabric of a city. The same applies for an ongoing claim for transformation away from car-centred to people-oriented planning, supporting street activities. This has been affirmed by conducted qualitative reviews of literature and international municipal planning documents as well as interviews with experts in the fields of urban planning, architecture or traffic engineering.

As the space is limited from façade to façade, a balanced distribution of the available space is required to meet the multiple claims. As the review of international planning documents shows, many cities exploit the potential of streets on a larger scale than Vienna. Neighbourhood-wide solutions such as Oslo's Car-free Liveability Programme [51], Barcelona's Superblocks [54,85,86] or Copenhagen's Climate resilient neighbourhood [43,49] are emerging and are globally discussed, all of which aim to use the potential of street networks and restructure streets layout in favour of GI, non-motorised, environmentally friendly and less space-consuming modes. 
The presented study, along with its recommendations, aims to fill the gap of a missing framework to plan and improve streets as multifunctional green public space in Vienna. It is developed to provide a better basis for urban road planning and design and delivers new standards for future decision processes. Thereby, future streets will still hold an important transport function and guarantee the mobility of people but will also have to support a resilient neighbourhood by meeting urgent demands of GI and sustainability. It is a paradigm shift from "moving cars quickly" to "providing safe access for all modes" [64] (p. 3) and towards providing reachable and connected green space.

Author Contributions: Conceptualisation, J.F., D.L. and L.L.; methodology, J.F., D.L. and L.L.; investigation, J.F., D.L. and L.L.; writing-original draft preparation, J.F. and D.L.; writing-review and editing, J.F., D.L. and L.L.; visualisation, J.F.; supervision, L.L.; project administration, L.L.; funding acquisition, L.L. and J.F. All authors have read and agreed to the published version of the manuscript.

Funding: This research was funded by Magistrat der Stadt Wien (MA19, MA18 and MA21A/B).

Institutional Review Board Statement: Not applicable.

Informed Consent Statement: Not applicable.

Data Availability Statement: Not applicable.

Acknowledgments: The presented results are drawn from studies carried out between 2019 and 2021 at the Institute of Landscape Architecture, University of Natural Resources and Life Sciences Vienna (Lilli Lička, Jürgen Furchtlehner, Daniela Lehner, Christina Kirchmair) and the Department for Social Work at the University of Applied Sciences Vienna, FH Campus Vienna (Christoph Stoik, Johannes Kellner, Katharina Kirsch-Soriano da Silva).

Conflicts of Interest: The authors declare no conflict of interest. Funders (representatives of the departments for city planning, architecture, landscape planning and land use planning Vienna) participated in the elaboration process and in workshops.

\section{References}

1. Coutts, C.; Hahn, M. Green Infrastructure, Ecosystem Services, and Human Health. Int. J. Environ. Res. Public Health 2015, 12, 9768. [CrossRef]

2. Hunter, R.F.; Cleland, C.; Cleary, A.; Droomers, M.; Wheeler, B.W.; Sinnett, D.; Nieuwenhuijsen, M.J.; Braubach, M. Environmental, health, wellbeing, social and equity effects of urban green space interventions: A meta-narrative evidence synthesis. Environ. Int. 2019, 130, 104923. [CrossRef]

3. Lennon, M.; Douglas, O.; Scott, M. Urban green space for health and well-being: Developing an 'affordances' framework for planning and design. J. Urban Des. 2017, 22, 778-795. [CrossRef]

4. NACTO-National Association of City Transportation Officials. Global Designing Cities Initiative. In Global Street Design Guide, 1st ed.; Island Press: Washington, DC, USA, 2016; ISBN 9781610917018.

5. UBA—Umweltbundesamt. Die Stadt von Morgen: Umweltschonend Mobil—Lärmarm—Grün—Kompakt—Durchmischt, 2nd ed.; Umweltbundesamt: Dessau-Roßlau, Germany, 2017; ISSN 2363832X.

6. Wang, J.; Banzhaf, E. Towards a better understanding of Green Infrastructure: A critical review. Ecol. Indic. 2018, 85, 758-772. [CrossRef]

7. Bowler, D.E.; Buyung-Ali, L.; Knight, T.M.; Pullin, A.S. Urban greening to cool towns and cities: A systematic review of the empirical evidence. Landsc. Urban Plan. 2010, 97, 147-155. [CrossRef]

8. Demuzere, M.; Orru, K.; Heidrich, O.; Olazabal, E.; Geneletti, D.; Orru, H.; Bhave, A.G.; Mittal, N.; Feliu, E.; Faehnle, M. Mitigating and adapting to climate change: Multi-functional and multi-scale assessment of green urban infrastructure. J. Environ. Manag. 2014, 146, 107-115. [CrossRef]

9. Coutts, C. Green Infrastructure and Public Health; Routledge: New York, NY, USA, 2016.

10. Stadt Wien MA 18. Lebensqualität in 91 Wiener Bezirksteilen. Bezirksprofile der Zufriedenheit mit der Wohnumgebung; Werkstattbericht 157; Stadt Wien, Magistratsabteilung 18—Stadtentwicklung und Stadtplanung: Vienna, Austria, 2016; ISBN 9783903003125.

11. City of Copenhagen. More People to Walk More: The Pedestrian Strategy of Copenhagen; The Municipality of Copenhagen, Technical and Environmental Administration: Copenhagen, Denmark, 2011.

12. Furchtlehner, J.; Lička, L. Back on the Street: Vienna, Copenhagen, Munich, and Rotterdam in focus. JoLA 2019, 14, 72-83. [CrossRef]

13. VCÖ, Verkehrsclub Österreich. Den Raum neu verteilen. Available online: https://www.vcoe.at/news/details/den-raum-neuverteilen (accessed on 15 October 2021). 
14. Wu, J.; Feng, Z.; Peng, Y.; Liu, Q.; He, Q. Neglected green street landscapes: A re-evaluation method of green justice. Urban For. Urban Green. 2019, 41, 344-353. [CrossRef]

15. Im, J. Green Streets to Serve Urban Sustainability: Benefits and Typology. Sustainability 2019, 11, 6483. [CrossRef]

16. Rodriguez-Valencia, A.; Ortiz-Ramirez, H.A. Understanding Green Street Design: Evidence from Three Cases in the U.S. Sustainability 2021, 13, 1916. [CrossRef]

17. Bendiks, S.; Degros, A. Traffic Space is Public Space. Ein Handbuch zur Transformation; Park Books: Zurich, Switzerland, 2019; ISBN 9783038601654.

18. Bosselmann, P. Urban Transformation; Island Press: Washington, DC, USA, 2008.

19. Mehta, V. The Street: A Quintessential Social Public Space; Routledge: New York, NY, USA, 2014; ISBN 9780415737296.

20. UBA-Umweltbundesamt. Straßen und Plätze neu Denken; Umweltbundesamt: Dessau-Roßlau, Germany, 2017.

21. Pregill, P. Urban Connections in the Contemporary Pedestrian Landscape; Routledge: New York, NY, USA, 2020.

22. Tzoulas, K.; Korpela, K.; Venn, S.; Yli-Pelkonen, V.; Kaźmierczak, A.; Niemela, J.; James, P. Promoting ecosystem and human health in urban areas using Green Infrastructure: A literature review. Landsc. Urban Plan. 2007, 81, 167-178. [CrossRef]

23. Zölch, T.; Maderspacher, J.; Wamsler, C.; Pauleit, S. Using green infrastructure for urban climate-proofing: An evaluation of heat mitigation measures at the micro-scale. Urban For. Urban Green. 2016, 20, 305-316. [CrossRef]

24. Klemm, W.; Heusinkveld, B.G.; Lenzholzer, S.; van Hove, B. Street greenery and its physical and psychological impact on thermal comfort. Landsc. Urban Plan. 2015, 138, 87-98. [CrossRef]

25. Navarrete-Hernandez, P.; Laffan, K. A greener urban environment: Designing green infrastructure interventions to promote citizens' subjective wellbeing. Landsc. Urban Plan. 2019, 19, 103618. [CrossRef]

26. Gälzer, R. Grünplanung für Städte: Planung, Entwurf, Bau und Erhaltung; Ulmer: Stuttgart, Germany, 2001; ISBN 3800131862.

27. Maryanti, M.R.; Khadijah, H.; Muhammad Uzair, A.; Megat Mohd Ghazali, M.A.R. The urban green space provision using the standards approach: Issues and challenges of its implementation in Malaysia. WIT Trans. Ecol. Environ. 2016, 210, 369-379. [CrossRef]

28. Stadt Wien MA 18. STEP 2025 Fachkonzept Grün- und Freiraum; Werkstattbericht 144; Stadt Wien, Magistratsabteilung 18Stadtentwicklung und Stadtplanung: Vienna, Austria, 2015; ISBN 978-3-902576-95-8.

29. Stadt Wien MA 18. Leitfaden zur Ermittlung der Grünraum Kennwerte; Stadt Wien, Magistratsabteilung 18-Stadtentwicklung und Stadtplanung: Vienna, Austria, 2017.

30. Grün Stadt Zürich. Die Freiraumversorgung der Stadt Zürich und ihre Berechnung: Methodenbeschreib und Anwendung; Grün Stadt Zürich: Zurich, Switzerland, 2019.

31. VCÖ, Verkehrsclub Österreich. Mehr Platz für bewegungsaktive Mobilität; VCÖ: Vienna, Austria, 2021; ISBN 9783903265080.

32. Lele, S.M. Sustainable Development. A Critical Review. World Dev. 1991, 19, 607-621. [CrossRef]

33. Open Data Österreich. Available online: https:/ / www.data.gv.at (accessed on 13 April 2020).

34. Stadt Wien. OGD Daten Download. Available online: https://www.wien.gv.at/stadtentwicklung/stadtvermessung/geodaten/ viewer/geodatendownload.html (accessed on 15 October 2021).

35. World Commission on Environment and Development. Our Common Future; Oxford University Press: London, UK, 1987.

36. Gehl, J. Cities for People; Island Press: Washington, DC, USA, 2010; ISBN 9781597265737.

37. Gössling, S. Why cities need to take road space from cars-and how this could be done. J. Urban Des. 2020, 25, 443-448. [CrossRef]

38. Carmona, M. Principles for public space design, planning to do better. Urban Des. Int. 2019, 24, 47-59. [CrossRef]

39. Francis, M. Urban Open Space: Designing for User Needs; Island Press: Washington, DC, USA, 2003.

40. Häberlin, U.W.; Furchtlehner, J. Öffentlicher Raum für alle? Raumaneignung versus Gemeinwesen in der Wiener Praxis. In Aneignung urbaner Freiräume: Ein Diskurs über städtischen Raum; Hauck, T.E., Hennecke, S., Körner, S., Eds.; Transcript Verlag: Bielefeld, Germany, 2017; pp. 177-199. [CrossRef]

41. Speck, J. Walkable City Rules; Island Press: Washington, DC, USA, 2018; ISBN 9781610918985.

42. Transport for London. Better Streets Delivered: Learning from Completed Schemes; Transport for London: London, UK, 2013.

43. Bund Deutscher Landschaftsarchitekten bdla. Grüne Infrastruktur: Zeitgenössische deutsche Landschaftsarchitektur. Green Infrastructure: Contemporary German Landscape Architecture; Birkhäuser: Basel, Switzerland, 2015.

44. Dunnett, N.; Clayden, A. Rain Gardens: Sustainable Rainwater Management for the Garden and Designed Landscape; Timber Press: Portland, OR, USA, 2007; ISBN 9780881928266.

45. Carmona, M. Public Places, Urban Spaces: The Dimension of Urban Design; Routledge: New York, NY, USA, 2021; ISBN 9781138067783.

46. Song, S.; Funk, P. Urban Streetscape Design; Design Media Publishing Limited: Hongkong, China, $2014 ;$ ISBN 9789881296726.

47. Reicher, C. Städtebauliches Entwerfen, 5th ed.; Springer: Berlin, Germany, 2017.

48. City of Copenhagen. CPH 2025 Climate Plan: A Green, Smart and Carbon Neutral City. Copenhagen; City of Copenhagen, Technical and Environmental Administration: Copenhagen, Denmark, 2012.

49. City of Copenhagen. Klimakvarter: Copenhagen's first Climate Resilient Neighbourhood, 2nd ed.; City of Copenhagen: Copenhagen, Denmark, 2016.

50. City of Stockholm. Environment Programme 2020-2023; City Executive Office: Stockholm, Swedem, 2020.

51. Oslo Kommune. The Car-Free Liveability Programme 2019; Oslo Commune: Oslo, Norway, 2019. 
52. Stadt Köln. Leitfaden für eine Wassersensible Stadt- und Freiraumgestaltung in Köln; Stadtentwässerungsbetriebe Köln: Köln, Germany, 2019.

53. Aslaug Lund, A.; Ramisch, T. Dänemark-Interview zum Titelthema. Gart. Landsch. 2021, 2, 12-17.

54. Lička, L.; Furchtlehner, J. Changing Streets: Individual Actions, Large-Scale Measures, and Ambitious Urban Climate Goals. In Urban Landscapes in High-Density Cities; Rinaldi, T., Ed.; Birkhäuser: Basel, Switzerland, 2019; pp. 100-116. [CrossRef]

55. Drlik, S. Das Schwammstadt Prinzip. Archit. Aktuell 2019, 3, 26-28.

56. Flecken, U.; Calbet i Elias, L. Der öffentliche Raum. Sichten, Reflexionen, Beispiele; Universitätsverlag der Technischen Universität Berlin: Berlin, Germany, 2011; pp. 13-17.

57. Kronenberg, J.; Haase, A.; Łaszkiewicz, E.A.; Antal, A.; Baravikova, A.; Biernacka, M.; Dushkova, D.; Filčak, R.; Haase, D.; Ignatieva, M.; et al. Environmental justice in the context of urban green space availability, accessibility, and attractiveness in postsocialist cities. Cities 2020, 106, 102862. [CrossRef]

58. Roloff, A. Bäume in der Stadt. Besonderheiten, Funktion, Nutzen, Arten, Risiken; Ulmer: Stuttgart, Germany, 2013 ; ISBN 9783800175987.

59. Stadt Wien MA 18. Hohe Lebensqualität in einer wachsenden Stadt? Ausgewählte Ergebnisse der Wiener Lebensqualitätsstudie 2018; Stadt Wien, Magistratsabteilung 18-Stadtentwicklung und Stadtplanung: Vienna, Austria, 2018.

60. Calderón-Argelich, A.; Benetti, S.; Anguelovski, I.; Connolly, J.T.; Langemeyer, J.; Baró, F. Tracing and building up environmental justice considerations in the urban ecosystem service literature: A systematic review. Landsc. Urban Plan. 2021, 214, 104130. [CrossRef]

61. Kabisch, N.; Haase, D. Green justice or just green? Provision of urban green spaces in Berlin, Germany. Landsc. Urban Plan. 2014, 122, 129-139. [CrossRef]

62. Sister, C.; Wolch, J.; Wilson, J. Got green? addressing environmental justice in park provision. GeoJournal 2010, 75, 229-248. [CrossRef]

63. Wen, C.; Albert, C.; Von Haaren, C. Equality in access to urban green spaces: A case study in Hannover, Germany, with a focus on the elderly population. Urban For. Urban Green. 2020, 55, 126820. [CrossRef]

64. Zavestoski, S.; Agyeman, J. Incomplete Streets: Processes, Practices, and Possibilities; Routledge: London, UK, 2015.

65. VCÖ, Verkehrsclub Österreich. In Wien mehr Fahrrad-Haushalte als Auto-Haushalte. Available online: https://vcoe.at/presse/ presseaussendungen/detail/vcoe-in-wien-mehr-fahrrad-haushalte-als-auto-haushalte (accessed on 15 October 2021).

66. Bork, H.; Klinger, S.; Zech, S. Kommerzielle und nicht-kommerzielle Nutzung im öffentlichen Raum; Stadtpunkte 16; Arbeiterkammer Wien: Vienna, Austria, 2015.

67. Furchtlehner, J.; Bautz, G. Tough Choice-Easy Decision. How to handle Installations in public urban space. Spool 2018, 5, 19-35.

68. Sim, D. Soft City, Building Density for Everyday Life; Island Press: Washington, DC, USA, 2019.

69. Psenner, A. Das Wiener Gründerzeit-Parterre-Eine analytische Bestandsaufnahme. Pilotstudi_Abschlussbericht; Städtebau TU Wien: Vienna, Austria, 2012.

70. Bielefeld, B. Raummaße Architektur: Flächen, Abstände, Abmessungen; Birkhäuser: Basel, Switzerland, 2018.

71. Thamm, U.; Weninger, A.; Gungl, B.; Studer, H. Öffentliche Räume in Stadtentwicklungsgebieten Wiens; Stadtpunkte 23; Arbeiterkammer Wien: Vienna, Austria, 2017.

72. Stadt Wien MA 18 und MA 19. STEP 2025 Fachkonzept Öffentlicher Raum; Werkstattbericht 175; Stadt Wien, Magistratsabteilung 18-Stadtentwicklung und Stadtplanung: Vienna, Austria, 2018; ISBN 9783903003415.

73. Stadt Wien MA 18. STEP 2025, Fachkonzept Mobilität; Werkstattbericht 145; Stadt Wien, Magistratsabteilung 18-Stadtentwicklung und Stadtplanung: Vienna, Austria, 2015; ISBN 9783902576972.

74. RVS. Richtlinien und Vorschriften für das Straßenwesen; Österreichische Forschungsgesellschaft Straße, Schiene, Verkehr Österreichische Forschungsgemeinschaft Straße und Verkehr: Wien, Austria, 2012.

75. Zimmermann, A. Elemente der Landschaft. Flächen, Abstände, Dimensionen; Birkhäuser: Basel, Switzerland, 2020; ISBN 9783035618563.

76. Vernon, S.; Vernon, S.; Tennant, R.; Garmory, N. Landscape Architect's Pocket Book Landscape Architect's Pocket Book; Routledge: London, UK, 2013.

77. City of San Francisco. San Francisco Parklet Manual 2.2; City of San Francisco: San Francisco, CA, USA, 2015.

78. Tadler, J.; Girardi, M. Bedarf und Potenziale. Eine Strategie Urbaner Öffentlicher Räume für Wien-Teil 1; Unpublished; Im Auftrag Magistrat der Stadt Wien, MA 18: Vienna, Austria, 2012.

79. Alexander, C.; Ishikawa, S.; Silverstein, M.; Jacobson, M.; King, I.; Angel, S. Eine Muster-Sprache. Städte, Gebäude, Konstruktion; Löcker: Vienna, Austria, 1995; ISBN 3854091796.

80. Stadt Wien MA19. Schanigarten—Ein Leitfaden; Stadt Wien, Magistratsabteilung 19-Architektur und Stadtgestaltung: Vienna Austria, 2019; Available online: https:/ / www.wien.gv.at/stadtentwicklung/studien/pdf/e000004.pdf (accessed on 29 October 2021).

81. Furchtlehner, J.; Lehner, D.; Lička, L. Transformation des öffentlichen urbanen Raums—Eine Werteverschiebung? In Interdisziplinäre Stadtforschung_Themen und Perspektiven; Kogler, R., Hamedinger, A., Eds.; Transcript Verlag: Bielefeld, Germany, 2021; pp. 283-307.

82. Klimakarte Stadt Wien. Available online: https://www.wien.gv.at/stadtentwicklung/grundlagen/stadtforschung/ stadtklimaanalyse.html (accessed on 30 November 2021). 
83. Bakradze, L. Öffentlicher Raum-Vom Verkehrsraum zum Lebensraum? In Der öffentliche Raum: Sichten, Reflexion, Beispiele; Flecken, U., Calbet i Elias, L., Eds.; Sonderpublikation des Instituts für Stadt und Regionalplanung Technische Universität Berlin: Berlin, Germany, 2011; pp. 49-59.

84. Haase, D.; Kabisch, S.; Haase, A.; Andersson, E.; Banzhaf, E.; Baró, F.; Brenck, M.; Fischer, L.K.; Frantzeskaki, N.; Kabisch, N.; et al. Greening cities-To be socially inclusive? About the alleged paradox of society and ecology in cities. Habitat Int. 2017, 64, 41-48. [CrossRef]

85. BCNUEJ-Barcelona Laboratory for urban Environmental Justice and Sustainability. Policy and Planning Tools for Urban Green Justice; BCNUEJ: Barcelona, Spain, 2021; Available online: http://www.bcnuej.org/wp-content/uploads/2021/04/ToolkitUrban-Green-Justice.pdf (accessed on 6 December 2021).

86. Ajuntament de Barcelona. Urban Mobility Plan of Barcelona 2013-2018; Ajuntament de Barcelona: Barcelona, Spain, 2014. 